House would lie between this and $\$ 35$ million.

In his letter to $\mathrm{Mr}$ Fuqua, Dr Press points out that a study carried out last year for $\mathrm{Mr}$ Carter by NSF and the Department of Education demonstrated problems caused by the deterioration of science and engineering education that "are pervasive and complex and will require determined and concerted effort by all sectors of society for their solution". David Dickson

\section{A brief respite}

The Glomar Challenger, the workhorse of the Deep Sea Drilling Project, docked last week at Southampton in preparation for the next stage (Leg 81) of the project. The previous leg was spent in the Bay of Biscay, to determine the rifting and subsidence history of the continental margin. Leg 81 will be spent near Rockall, a few hundred miles to the west of Scotland, studying the variations of subsidence across the ocean-continent boundary.

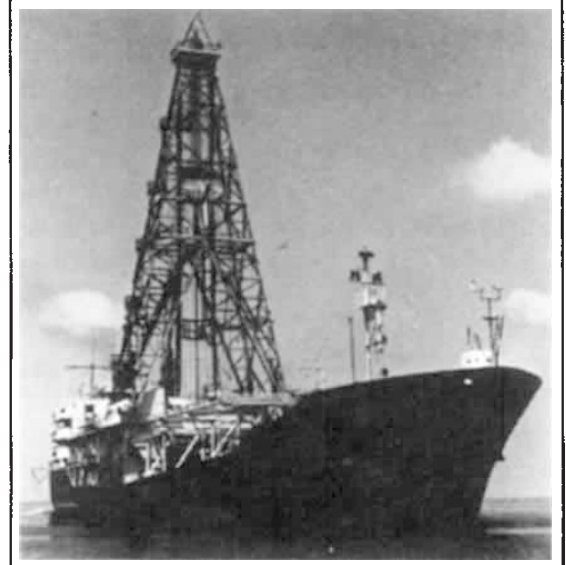

Challenger on the crest of a wave

The Deep Sea Drilling Project is at present riding on a wave of enthusiasm for its scientific record, and has so far done well in President Reagan's financial obstacle race. Glomar Challenger's drilling operations are funded for at least another two years, with a 1982 budget of $\$ 26$ million. Of this, $\$ 12$ million will come from Britain, Germany, France, the Soviet Union and Japan, while the bulk of the United States contribution will be provided by the National Science Foundation.

Future plans are, however, less certain because of the debate within the foundation over the competing merits of Glomar Explorer - the converted exCIA submarine-dredger. Although vastly more expensive (its expected cost lies between $\$ 500$ million and $\$ 1,000$ million over ten years), the Explorer programme would be half financed by the oil industry on the strength of its considerable oilhunting potential. The scientific issues are complex, however; and a decision from Congress on whether or not to fund initial Explorer development is expected in October.
EEC hormone legislation First another report

\section{Brussels}

Progress of a sort was achieved by the European Community's agricultural ministers in Brussels last week when they discussed the problem of a total ban on hormone use in livestock breeding. They decided that Community law should ban stilbenes and thyrostatics as growth promoters in livestock breeding even though these hormones are already outlawed in all the member states.

And to serve as a figleaf for the lack of agreement on other growth promoters, it was decided to wait for a scientific report before dealing with the natural hormones oestradiol, progesterone, testosterone and the synthetic hormones trembolone and zeranol. A deadline of nine months has been set for this report but quite how it will help to solve what is essentially a political problem nobody is quite sure.

Details of how this scientific report will be compiled are also still hazy. Presumably, the same national experts who form the various scientific committees advising the European Commission on veterinary or nutritional matters will assess the present state of knowledge.

European consumer groups are planning to write to their ministers to demand that these experts are chosen for their impartiality. In fact, anyone nominated by a national government will have already contributed towards that government's position on hormones. The scientific report may therefore end up reflecting only the existing divisions of opinion.

The United Kingdom and Ireland are the strongest opponents of a blanket ban, but producers in other member states are lobbying effectively in the other direction. France, Denmark and Italy want legislation to be as severe as possible - and it was the ruling of an Italian court to ban veal sales which started the whole affair. The new French agriculture minister, Edith Cresson, stressed at the Council that France would not be bound by the conclusions of the scientific report. Belgium and Germany in theory already ban the use of all hormones.

Consumer groups are also incensed by the ministers' reluctance to thrash out the ways and means to enforce a ban of any kind. Natural hormones are notoriously difficult to detect and the various member states do not all have the same reputation for the effective policing of detectable substances.

What has been achieved is the right for any member country to prevent the entry from another EEC country of meat which contains hormones such as stilboestrol, diethylstilboestrol, dienoestrol and hexoestrol. And those member states with legislation which bans other hormones can carry on as before.

In nine months' time, the European
Community will still have to decide between a policy which favours the consumer approach of banning unless proved safe and one favouring the industry's attitude of carrying on until a substance is known to be dangerous to human health - which is the choice of the United States.

Jasper Becker

\section{Third World development}

\section{Proper priorities}

\section{Washington}

The US Agency for International Development (AID) is continuing to pick up the pieces following the failure of the Carter Administration to convince Congress of the need for a new Institute for Scientific and Technological Cooperation to act as a focus for research on the needs of Third World countries.

Earlier this month the agency announced that as part of a general reorganization, a new Bureau of Science and Technology was to be established. Furthermore the title of "assistant administrator for development support" will be changed to "senior assistant administrator for science and technology", a position that will have responsibility for the bureau.

One of the aims of this reorganization, according to agency officials, is to strengthen the research activities of AID which have in the past been of lower priority than more conventional technical aid programmes. This was one of the reasons quoted for establishing the Institute for Scientific and Technological Cooperation, a body which would remain under the same umbrella as AID, but operate independently with its own board of advisers.

The parallel between the goals of the illfated institute and the newly proposed bureau is strengthened by the fact that $\mathrm{Mr}$ Reagan's appointee to head the bureau, $\mathrm{Dr}$ Nyle Brady, had previously been successfully wooed by the Carter Administration as its proposed director for the institute. Dr Brady will have responsibility for the administration of a wide range of centrally-funded research and development programmes, some of which were to have been shifted from AID to the new institute.

The Carter Administration had originally proposed significant increases in research support for these areas which would have virtually doubled the AID budget for research and development to $\$ 229.8$ million in the fiscal year 1982 . The Reagan Administration has reduced this dramatically to a request for $\$ 134.5$ million, with large cuts, for example, in support for agricultural research on food production in Africa.

Even with these cuts, however, AID officials point out that the Administration's request for science and technology programmes for 1982 is 40 per cent higher than the amount spent on 
research by AID in 1980. A particularly significant increase is in energy research, scheduled to grow from $\$ 3.4$ million in 1980 to $\$ 16.3$ million in 1982 .

The impact the increase in funds and the internal reorganization will have remains controversial. Those in Congress who argued most strongly for the institute are somewhat sceptical.

This scepticism is reflected in a report from the House Foreign Affairs Committee on the AID budget request, which has included as a separate item a proposed $\$ 10$ million (reduced from President Carter's requested $\$ 18$ million) for the support of scientific and technological cooperation with developing countries. The committee has reinserted this money into the broader category of "selected development activities".

In fact, much of this money will be spent in a way comparable to what the institute would have done, but through a different agency, the National Academy of Sciences. AID has agreed to provide $\$ 35$ million of its science and technology funds over the next five years to a new grants programme established under the academy's Board on Science and Technology for International Development.

The grants, which will be $\$ 5$ million for 1981 and increase to $\$ 10$ million by the middle of the decade, will be spent largely on supporting research activities in the developing countries on projects selected by an advisory board. "One of our principal goals is to help developing countries build up their research capabilities, precisely the request that they were making at UNCSTD (the United National Conference on Science and Technology for Development) in Vienna in 1979", says the board's staff director, Dr Victor Rabinowitch.

When the grants programme is added to its more traditional activities, such as arranging seminars on Third World problems, the board will begin to resemble a scaled-down version of the Institute for Scientific and Technological Cooperation.

Furthermore its relative autonomy from AID goes some way to meeting the objections of those who argued that, as put forward by the Carter Administration, the inclusion of the institute under the umbrella of development aid bodies would have stifled its flexibility. David Dickson

\section{Polish economic reform}

\section{Self-governance wins}

\section{Warsaw}

The latest Polish plans for economic reform, discussed in considerable detail during the recent extraordinary Party congress, include a major shake-up for Polish science and technology. The basis of the proposed new economic model is a switch from rigid central planning of industrial production to a degree of "selfgovernance" (samorzadnosc) - a word introduced into the Polish political lexicon with the rise of the independent trade union movement last August.

The new system, which is to be introduced in four phases over the next 18 months, will allow for more public and expert discussion in advance of overall production plans and delegate to factories initiative for deciding how they fit in with the overall targets.

As in Hungary, the authorities will steer production by a system of financial incentives, but factory managements will have considerable responsibility for decision-making on modernization and technological innovation. One of the major charges laid against the previous Gierek government in the preamble to the new plan is that autocratic planning blocked technical innovation. At the same time, many of $\mathrm{Mr}$ Gierek's prestigious schemes are being dropped. The "Program-Wisla", for example, which was totally to remodel Poland's major waterway by the end of the century, has been cut back to its environmental and agricultural components. The schemes for hydroelectric dams and the straightening of rivers have been dropped sine die.

Other harm done by Gierek's policies will not be so easily remedied. Discrimination against the private farmer in the pricing and supply system ran agriculture down to a level where even the new rationing system cannot ensure supplies of basic home-produced foods. The abolition of the small pharmaceutical cooperative factories in the 1970s has meant that Poland has had to shop abroad for a wide variety of drugs whose production runs were too small for the state pharmaceutical enterprise Polfa - and when hard currency ran out, so did the supply of even the most essential drugs. The international relief operation to ensure vital supplies now being mounted jointly by Solidarity and the Polish Ministry of Health is a strange contrast with the anxiety in the mid-1960s in the United Kingdom that Polish drugs might undercut the domestic products.

Although the new plan pays lip-service to the strengthening of scientific and technical ties with other (especially Comecon) countries, it is also clear that for the present Poland will have to rely mainly on homebased technology.

A reorganization of the responsible ministries is also on the cards. One is for a State Committee for Technical Progress responsible to the Prime Minister. The new body would be unique in the Comecon bloc in dealing only with technology, and may point to an ultimate break-up of the Ministry of Science, Higher Education and Technology. Straws in the wind include the appointment last month of a mining specialist, Jerzy Nawrocki, as Minister of Science, Higher Education and Technology, and the plans discussed at the congress for a complete review of the country's industrial research institutes and the closure of those not cost effective.

Whatever the final form of the reorgani- zation, one change is certain - a revision of the present practice of financing science by "problems" ostensibly related to economic needs and organized into a cumbersome hierarchy of priorities. Among likely innovations are direct research contracts between industry and the universities or academy institutes and the allocation of funds for basic research directly to the institutions concerned.

For the moment, however, virtually all such funding will come in non-convertible zloty. Hard currency for the purchase of equipment, reagents or journals from the West is simply not to be had; according to one leading physicist, only two subscriptions to Nature are now authorized for the whole of Warsaw.

Vera Rich

\section{British Technology Group}

\section{Mixed marriage}

Last week, Britain's National Enterprise Board and the National Research Development Corporation finally merged. The British Technology Group, as the two are now called, has been in the offing since $\mathrm{Sir}$ Frederick Wood was appointed chairman of both the board and the corporation at the beginning of the year. His plan for a merger has now been accepted by the government, although legislation to give the group formal status will not be possible until 1983.

The plan is that the group will offer more streamlined services to innovators seeking backing for their ventures than either of the parent organizations. The merger will also eliminate competition between the board and corporation for the same projects.

The function of the former corporation to support research and development into potentially marketable innovations will be largely taken over by the group's technology transfer division. And the board's experience in raising finance to invest in industry will be incorporated into the new investment and operations divisions, the latter being responsible for returning investments to the private sector.

Both parent organizations have been widely criticized in the past. The board, which was originally set up in 1965 by the then Labour government with the potent title of Industrial Reconstruction Corporation, has since been substantially curtailed. And the corporation has been criticized mainly by academics for not being adventurous enough in supporting their innovations and persuading industry to take them up. The British Technology Group is intended primarily to marry the corporation's access to innovators with the board's financial expertise. There is to be a new liaison team whose prime responsibility will be to scour the universities more aggressively than in the past.

The group is also to have a new corporate development unit to develop strategies for investment. Areas of priority are advanced manufacturing and biotechnology. A 